Vol.04, No.02, Bulan 2018

Doi: $10.24198 / \operatorname{cosmogov} . v 2 \mathrm{i} 2 . x x x x x$

\title{
ANALISIS KEBIJAKAN TRAVEL BAN OLEH DONALD TRUMP
}

\author{
Muhammad Arraf Rezkia Rachman \\ Program Studi Hubungan Internasional Fakultas Ilmu Sosial dan Ilmu Politik \\ Universitas Padjadjaran
}

Email: muhammad17333@mail.unpad.ac.id

\begin{abstract}
ABSTRAK
Dengan maraknya peristiwa terorisme di berbagai belahan dunia tentunya mengharuskan tiap negara untuk mendirikan pertahanan dan saling bekerja sama untuk memberantas permasalahan ini sampai ke akarnya. Kebijakan-kebijakan tiap negara maupun internasional yang ideal pun dibutuhkan untuk menekan angka teror yang kian bertambah tiap tahunnya. Cara-cara yang diambil dari tiap negara pun berbeda-beda, sesuai dengan keadaan negara mereka sendiri dan penduduknya. Sejak awal Donald Trump mencalonkan diri sebagai presiden di tahun 2015 lalu, ia sudah memiliki cukup banyak pendukung. Mereka yang mendukung Trump, misalnya, merasa terhubung dengan visi Amerika yang telah dia promosikan sejak awal kampanyenya, yaitu "Make America Great Again". Akibatnya, mereka telah mengubah pemahaman mereka tentang masyarakat Amerika berdasarkan deskripsi yang diberikan oleh Trump. Kesamaan pandangan antara Trump dan para pendukungnya tercermin dalam bagaimana mereka memiliki konsepsi tertentu tentang identitas nasional Amerika, lemahnya perekonomian dan ketidakpuasan terhadap pemerintah, serta persepsi negatif terhadap kelompok nasional lainnya. Trump berpendapat bahwa pada pemerintahan Obama mempromosikan nilai-nilai kemanusiaan internasional, kosmopolitanisme, dan transformasi ekonomi nasional ke dalam pasar yang kompetitif secara global namun menomor duakan pembelaan hak-hak warga Amerika Serikat.
\end{abstract}

Kata kunci: Donald Trump, Kebijakan, Identitas.

\begin{abstract}
With the rise of terrorism events in various parts of the world would require each country to establish a defense and cooperate with each other to eradicate this problem to the root. Even ideal national and international policies are needed to reduce the growing number of terror annually. The ways taken from each country vary, according to the circumstances of their own country and its inhabitants. Since the beginning of Donald Trump running for president in 2015, he already has enough supporters. Those who support Trump, for example, feel connected to the American vision he has promoted since the start of his campaign, "Make America Great Again". As a result, they have changed their understanding of American society based on the description given by Trump. The similarity of views between Trump and his supporters is reflected in how they have a certain conception of
\end{abstract}


Vol.04, No.02, Bulan 2018

Doi: $10.24198 / \operatorname{cosmogov} . v 2 \mathrm{i} 2 . x x x x x$

American national identity, economic weakness and dissatisfaction with government, and negative perceptions of other national groups. Trump argues that the Obama administration promotes international humanitarian values, cosmopolitanism, and national economic transformation into a globally competitive marketplace but is a sign of the defense of the rights of citizens of the United States.

Keywords: Donald Trump, Policy, Identity.

\section{PENDAHULUAN}

Trump, mengutamakan hak-hak warga negara Amerika Serikat terdahulu dan mengabaikan konsepkonsep hak yang universal (Korostelina, 2017). Dia secara khusus menargetkan kelompok yang tidak memiliki kewarganegaraan Amerika: orang asing yang tidak memiliki dokumen, pengungsi Suriah, atau imigran Muslim yang mencoba masuk ke A.S.

Setelah menangnya Trump dalam pemilihan presiden Amerika Serikat pada tahun 2017, Trump mengabulkan salah satu janji kampanye nya dengan mengeluarkan perintah eksekutif (keputusan presiden) berjudul "Protecting the Nation from Foreign Terrorist Entry into the United States" atau Perintah Eksekutif 13769. ${ }^{1}$ Kebijakan ini juga sering disebut sebagai Travel Ban atau Muslim Ban ${ }^{2}$ karena dengan perintah eksekutif ini diturunkannya jumlah pengungsi yang masuk ke Amerika Serikat pada 2017

1 "Public Inspection: Presidential Document: Defense and National Security: Foreign Terrorists; Measures to Prevent U.S. Entry (EO 13769)". Federal Register.

${ }^{2}$ AS menambah Korea Utara kedalam Travel Ban, BBC ["Mr Trump's original ban was sampai 50.000, menangguhkan Program Penerimaan Pengungsi AS (USRAP) selama 120 hari, menghentikan masuknya pengungsi Suriah tanpa batas waktu, mengarahkan beberapa sekretaris kabinet untuk menangguhkan masuknya negara yang tidak memenuhi standar penanganan berdasarkan undang-undang imigrasi AS selama 90 hari, dan termasuk pengecualian atas kasus per kasus. Negara-negara ini adalah negara yang mayoritas penduduknya beragama muslim, seperti Iran, Irak, Libya, Somalia, Sudan, Suriah, dan Yaman. Lebih dari 700 pelancong yang ditahan, dan lebih dari 60,000 visa "dicabut sementara." 3

Donald Trump memiliki kekhawatiran apabila negaranya dimasuki orang asing atau imigran dengan mudahnya maka negaranya akan terancam dengan adanya kemungkinan terorisme. Namun Apabila kita melihatnya dari sisi terorisme maka kita tidak akan

highly controversial, as it affected six majority-Muslim countries, and was widely labelled a "Muslim ban".]

${ }^{3}$ Executive Order 13769. Wikipedia (https://en.wikipedia.org/wiki/Executive_Orde r_13769) 
Vol.04, No.02, Bulan 2018

Doi: $10.24198 /$ cosmogov.v2i2.xxxxx

menemukan satupun kejadian terorisme di Amerika yang disebabkan oleh pengungsi dan warga negara dari Iran, Irak, dan Suriah. Kasus terorisme di Amerika justru disebabkan oleh teroris dari Arab Saudi, Mesir, Turki dan Lebanon seperti kejadian 11 September. Bukti yang diperlihatkan oleh sejarah serangan teroris di Amerika tidak menjadi dasar penentuan pembatasan negara ini dan apabila kita melihat dari sisi lain, Irak, Iran, dan Suriah sudah bersekutu dengan Amerika dalam perlawanan terhadap teroris. Ulasan ini menunjukkan bahwa persoalan teroris tidak menjadi pertimbangan utama meskipun menjadi pembungkus.

$$
\text { Isu politik ini tengah }
$$
diperdebatkan tidak hanya di antara masyarakat Amerika Serikat, namun juga di berbagai negara di dunia, negara-negara mayoritas muslim maupun tidak. Kebijakan yang kontroversial ini memiliki kelompok pro dan kontra dari berbagai kalangan di Amerika Serikat, maka dari itu, dengan menganalisis isu politik tersebut secara empiris dan objektif, dapat dipertimbangkan kelebihan serta kekurangan yang dimiliki kebijakan Travel Ban atau Muslim Ban ini. Masyarakat AS diarahkan oleh pemerintahnya untuk menganggap orang-orang yang sebenarnya atau seharusnya "asing" atau "imigran". Sasaran prasangka ini sebenarnya tidak perlu asing sama sekali; ini cukup untuk dianggap seperti itu. Imigran dari negara lain sering diidentifikasi sebagai orang asing, tetapi tidak berarti semua negara asal sama-sama berasosiasi dengan prasangka negatif. Di Eropa Barat prasangka negatif saat ini diarahkan di atas semua terhadap orang-orang dari budaya lain - biasanya berarti orang berambut gelap dari negara-negara Muslim - sedangkan terhadap Swedia, misalnya, prasangka yang positif tersebar luas. Contoh ini dengan jelas mengilustrasikan tiga karakteristik prasangka: Pertama, pengkategorian orang sebagai "asing" adalah fleksibel. kedua, prasangka tergantung pada konteks, dengan target sikap anti-imigran yang berbeda di berbagai tempat dan era sejarah. Dan ketiga, kita lihat di sini caranya sikap anti-imigran saling terkait erat dengan elemen lain, yaitu, rasisme dan sikap anti-Muslim. (Zick, Küpper, \& Andreas, 2011) Yang mana pengarahan - pengarahan tersebut akan berpengaruh buruk untuk keberagaman Negara Amerika Serikat itu sendiri.

\section{HASIL DAN PEMBAHASAN}

Hanya tujuh hari setelah dilantiknya Donald Trump sebagai presiden ke-45 Amerika Serikat, Trump langsung menepati janji politik pada masa kampanyenya untuk menangguhkan imigrasi dari negaranegara yang rawa dengan terorisme. Donald Trump mengatakan pada pidatonya di Pheonix,

"Dan jika orang tidak menyukainya, kita harus memiliki negara. Negara-negara yang di mana imigrasi akan ditangguhkan akan 
Vol.04, No.02, Bulan 2018

Doi: $10.24198 /$ cosmogov.v2i2.xxxxx

mencakup tempat-tempat seperti Suriah dan Libya. Kita akan menghentikan puluhan ribu orang yang datang dari Suriah."

Donald Trump mengkhawatirkan pengungsi dari Suriah yang mungkin berhubungan dengan kelompok ekstrimis seperti ISIS. Dengan begitu, Trump mengajukan diperketatnya pemeriksaan untuk semua imigran dari negara-negara tersebut, bahkan seperti mengidentifikasi ideologi yang mereka anut. Padahal, pemeriksaan yang telah dilakukan selama ini pun sudah sangat ketat dan memprihatinkan, mengetahui proses yang dilalui dapat memakan waktu sampai dua tahun lamanya dan hanya kurang dari $1 \%$ dari pengungsi yang dapat masuk ke Amerika Serikat. ${ }^{4}$

Mayoritas warga Amerika percaya bahwa keamanan nasional merupakan motivasi utama di balik kebijakan Presiden Donald Trump yang membatasi sementara pelancong dari negara-negara berpenduduk mayoritas Muslim untuk datang ke AS, menurut sebuah survey yang dilakukan oleh Associated Press dan University of Chicago's NORC Centre for Public Affairs Research.

Survey tersebut juga menunjukkan bahwa pandangan masyarakat AS sangat sesuai dengan afiliasi politik mereka: 87 persen orang Republik percaya bahwa perintah eksekutif tersebut merupakan tentang keamanan nasional dibandingkan dengan hanya 41 persen Demokrat. 64

\footnotetext{
4 "FAQ: Refugees and resettlement." International Rescue Committee
}

persen Demokrat juga lebih cenderung percaya bahwa kebijakan itu Islamofobia, karena hal itu bertujuan untuk melarang umat Islam masuk ke negara tersebut. Hanya 34 persen anggota Partai Republik yang setuju. Selain itu, Partai Republik dan Demokrat berselisih mengenai dilakukannya pengkajian kelegalan hukum terhadap kebijakan, dengan 73 persen anggota Partai Republik menentang dan 82 persen Demokrat mendukung.

$\begin{array}{clr}\text { Setelah } & \text { Donald } & \text { Trump } \\ \text { menandatangani } & \text { kebijakan tersebut }\end{array}$ pada tanggal 27 Januari 2017, tidak sedikit pihak yang menentangnya. Terdapat empat wilayah yang menolak kebijakan ini untuk dilaksanakan, yaitu Washington, Virginia, Massachusetts, dan New York. Pelaksana tugas Jaksa Agung, Sally Yates, yang belum lama dilantik pada akhir masa jabatan Obama, dipecat oleh Trump karena menolak kebijakan tersebut karena tidak yakin perintah eksekutif itu sesuai hukum. Lebih lagi, Trump membolehkan pengungsi yang beragama Kristen, menunjukkan diskriminasi dan perilaku yang Islamophobic.

Kebijakan ini menelan lebih banyak kekacauan dan kemarahan di seluruh negara, dengan para pemudik ditahan di bandara, keluarga panik mencari kerabat dan pemrotes berbaris melawan tindakan sweeping yang questions-about-refugees-and-resettlement) 
Vol.04, No.02, Bulan 2018

Doi: $10.24198 /$ cosmogov.v2i2.xxxxx

diblokir oleh beberapa pengadilan federal.

Demonstrasi pertama kali dimulai sehari setelah Trump menandatangani perintah tersebut. Di Washington D.C., ratusan demonstran berkumpul di luar Gedung Putih, beberapa tanda bertuliskan, "Kami semua adalah imigran di Amerika." Demonstrasi juga dilipat di Detroit Metropolitan Airport dan Minneapolis-St. Paul International Airport, serta di pinggiran kota Chicago, di mana sebuah kelompok Yahudi mengadakan demonstrasi untuk mendukung umat Islam. ${ }^{5}$

Namun, berbagai revisi untuk kebijakan yang dianggap sembrono oleh sebagian masyarakat tersebut dilakukan. Trump pun mengeluarkan Perintah Eksekutif 13780. ${ }^{6}$ Trump berkata kebijakan baru ini "versi yang disederhanakan, benar secara politis" dari perintah eksekutif sebelumnya. ${ }^{7}$ Dapat disimpulkan dalam kebijakan ini yang berubah adalah Irak dan Sudan tidak lagi dimasukkan didalam travel ban namun akan melaksanakan pemeriksaan tambahan saat memasuki imigrasi, visa yang dikeluarkan sebelum kebijakan dilaksanakan akan tetap berlaku, penduduk tetap yang tinggal di AS dan pemilik green card tidak termasuk dalam larangan tersebut, pengungsi Suriah tidak dilarang lagi tanpa batas waktu, dan kebijakan yang baru tidak memprioritaskan orang

\footnotetext{
${ }^{5}$ New Trump travel ban faces instant backlash. CNN
}

Kristen dalam revisi. Pada bulan September, Chad, beberapa pejabar Venezuela, dan Korea Utara ditambahkan kedalam daftar larangan travel ban.

Namun, Sejak 11 September, tidak ada seorangpun yang terbunuh dalam serangan teroris oleh imigran dari negara-negara yang termasuk dalam larangan tersebut. Serangan besar seperti serangan 11 September di New York, pemboman maraton Boston dan serangan klub malam Orlando dilakukan oleh orang-orang dari negara-negara yang tidak termasuk dalam daftar, seperti Arab Saudi, Mesir dan Kirgistan, atau oleh penduduk AS sendiri. Selain itu, kurang dari satu dari empat Muslim Amerika yang melakukan kegiatan terkait terorisme memiliki keluarga di negara-negara tersebut.

Kebijakan yang dianggap "tidak seperti Amerika" ini bisa membuat Amerika Serikat tidak aman. Mantan jihadi Abu Abdullah mengatakan kepada CNN bahwa kebijakan tersebut dapat "memainkan propaganda mereka, untuk memperjelas kepada orang-orang yang risau, bahwa ini adalah perang terhadap Islam dan semua Muslim."

Beberapa negara mayoritas Muslim lainnya seperti Saudi Arabia, Turki, Lebanon, Uni Emirat Arab, Mesir, dan Indonesia tidak dimasukkan kedalam daftar negara yang dilarang.

\footnotetext{
${ }^{6}$ Executive Order 13780. Wikipedia (https://en.wikipedia.org/wiki/Executive_Order 13780)
${ }^{7}$ Ibid
} 
Vol.04, No.02, Bulan 2018

Doi: $10.24198 /$ cosmogov.v2i2.xxxxx

Mereka memiliki satu kesamaan, yaitu adanya bisnis milik Trump yang dibangun di negara-negara tersebut. Hal ini mengimplikasikan bahwa perkataan Trump sebelumnya yaitu telah menyerahkan bisnisnya kepada keluarganya untuk mencegah terjadinya konflik, tidak sepenuhnya akurat. Ia masih terlihat terlalu berkecimpung kedalam bisnis nya dan menyampuri urusan negara dan urusan pribadinya.

Jika dilihat dari statistik yang ada, tidak ada yang perlu ditakutkan akan terorisme dari pengungsi. Dari 784,000 pengungsi yang bermukim di Amerika Serikat selama 15 tahun terakhir, hanya tiga orang ditangkap karena merencanakan kegiatan teroris (Nowrasteh, 2016). Kemungkinan terbunuh dalam serangan teroris yang dilakukan oleh seorang imigran adalah 1 banding 3,6 juta, dan itu termasuk total kematian dalam serangan 9/11. Penambahan negara Venezuela dan Korea Utara hanya sesuatu tidak lebih dari sekedar penyamaran bahwa kebijakan ini bukanlah kebijakan Muslim Ban.

Negara Indonesia memang tidak terkena oleh kebijakan tersebut, namun Presiden Joko Widodo menegaskan bahwa keadilan dan kesetaraan harus diperjuangkan. Di Jakarta, semakin banyak orang Indonesia yang membuat petisi dan menginginkan Donald Trump dan bisnisnya dilarang dari Indonesia yang merupakan negara berpenduduk mayoritas Muslim terpadat di dunia setelah Trump melarang kaum Muslim memasuki Amerika Serikat.

Menanggapi larangan tersebut, KBRI di Washington DC telah memberi peringatan kepada warga negara Indonesia di AS untuk tetap tenang, namun waspada. Kedutaan Besar juga mengajak warga negara Indonesia untuk menghormati undangundang A.S. dan membantu memastikan ketertiban umum di lingkungan mereka, namun juga mereka harus memahami hak mereka jika terjadi masalah dan mengarahkan mereka ke situs American Civil Liberties Union (ACLU). ${ }^{8}$

Menurut pendapat saya, dalam menerapkan pembatasan masuk imigran dari negara-negara muslim, hal itu melanggar norma keadilan. Seperti semua orang tahu, kebijakan tersebut telah membuat orang-orang terdampar di luar negeri yang telah tinggal di Amerika Serikat dan juga orang-orang yang telah diberi izin untuk datang dan telah membuat rencana kehidupan. Untuk mencabut hak orang untuk memasuki Amerika Serikat yang sebelumnya telah mereka berikan dan mereka tidak melakukan kesalahan itu tidak adil.

Administrasi pemerintahan Trump secara implisit mengakui kegagalan moral dalam mengubah kebijakan ini sehingga tidak lagi membatasi masuknya pemegang kartu

\footnotetext{
${ }^{8}$ Indonesia not Affected by Trump's Travel Ban: Presiden Jokowi. Sekretarian Kabinet Republik Indonesia.
} 
Vol.04, No.02, Bulan 2018

Doi: $10.24198 /$ cosmogov.v2i2.xxxxx

hijau (yaitu orang yang berhak tinggal di AS sebagai penduduk tetap), namun ini masih menyisakan banyak orang yang tidak melakukan kesalahan apapun di luar negeri dan kehidupan mereka terganggu. Misalnya, siswa tidak bisa masuk untuk melanjutkan atau memulai studi mereka, pekerja dengan izin selain kartu hijau tidak dapat kembali, dan seterusnya.

Tujuan sebenarnya dari larangan tersebut bukanlah sekedar untuk membendung arus teroris. Ini untuk mempertahankan adanya intimidasi terhadap umat Islam dan untuk menunjukkan bahwa mereka tidak dapat sepenuhnya bertahan. Dengan mempertahankan mereka sebagai orang luar di negara mereka sendiri, kebijakan tersebut dengan mudah menargetkan mereka sebagai tersangka.

Kebijakan tersebut melanggar prinsip moral bahwa itu adalah salah jika melakukan diskriminasi atas dasar agama. Tujuh negara yang warganya tidak diizinkan masuk adalah negara penduduk mayoritas Muslim yang cukup besar. Trump sendiri secara implisit mengakui bahwa membedakan antara agama itu salah dengan tidak mengakui bahwa dia melakukannya. Kebijakan ini jelas dan sengaja ditujukan untuk membatasi masuknya umat Islam.

Terlebih lagi kebijakan ini telah melanggar hukum yang telah ditetapkan sebelumnya. Dalam perintahnya, Trump mengutip sebuah undang-undang imigrasi tahun 1952 yang memberi presiden kemampuan untuk menangguhkan masuknya warga yang tidak memiliki dokumen ke AS saat dia menganggapnya "merugikan kepentingan Amerika Serikat."

Sebuah revisi undang-undang tahun 1965, bagaimanapun, mengatakan bahwa individu tidak dapat "didiskriminasikan dalam penerbitan visa imigran" karena "ras, jenis kelamin, kewarganegaraan, tempat lahir atau tempat tinggal mereka".

Kurangnya hubungan rasional antara pengungsi dari tujuh negara yang tercantum dalam Perintah Eksekutif dan ancaman terorisme sangat bermasalah dan sudah menghadapi banyak tantangan hukum di pengadilan nasional di AS. Ketika ditantang oleh badan PBB atau pengadilan internasional, kemungkinan besar hal itu juga akan bertabrakan dengan hukum internasional.

Amerika Serikat melanggar kewajibannya sebagai penandatangan Refugee Convention. Secara khusus, perintah eksekutif melanggar prinsipprinsip non-diskriminasi (membatasi pengungsi berdasarkan ras, agama, atau negara asal), dan pembebasan dari tindakan pengecualian (menerapkan tindakan pengecualian terhadap pengungsi semata-mata karena kewarganegaraan).

Pasal 26 Kovenan Internasional tentang Hak Sipil dan Politik (ICCPR) mensyaratkan bahwa pemukiman kembali pengungsi dilakukan dengan cara yang menjamin perlindungan yang sama tanpa diskriminasi atas dasar apapun dan secara eksplisit melarang 
Vol.04, No.02, Bulan 2018

Doi: $10.24198 /$ cosmogov.v2i2.xxxxx

dasar-dasar seperti agama atau asal negara.

Dan juga, pasal 3 dari Konvensi 1951 yang berkaitan dengan Status Pengungsi melarang diskriminasi dalam penerapan konvensi ini dengan alasan ras, agama atau negara asal. ${ }^{9}$ Selanjutnya, pasal 33 Konvensi membuatnya ilegal untuk mengusir atau mengembalikan pengungsi ke tempat risiko penganiayaan atau bahaya. Tak satu pun dari kewajiban internasional yang ditetapkan dalam Konvensi ini dapat pengecualian. ${ }^{10}$

Konsekuensi dari kebijakan tersebut tidak terbatas hanya pada umat Islam. Semua etnis minoritas terpengaruh karena tidak mungkin membedakan Muslim dari kelompok lain. Setiap orang cokelat mungkin dianggap Muslim. Hal ini meningkatkan resiko ratusan ribu orang dan komunitas mereka, sekolah mereka, dan tempat ibadah mereka. Dan pada akhirnya hal ini akan mempengaruhi semua orang karena kita berbagi komunitas ini, sekolah-sekolah ini, dan ruang publik yang berisi tempat ibadah kita. Bahaya untuk beberapa membahayakan kita semua. Dalam melanggar perjanjian untuk saling menghormati yang membuat masyarakat bisa hidup bersama-sama, kekerasan dan segala dampak negatif yang mungkin akan segera terjadi telah mengurangi kualitas kehidupan publik. \begin{tabular}{llr}
\multicolumn{3}{c}{ Sektor ekonomi Amerika dapat } \\
diprediksi & akan menderita jika \\
kebijakan & ini terus dilakukan. \\
Kebijakan & diskriminatif & Trump \\
mengancam & paradigma pertukaran
\end{tabular} ilmiah global yang terbuka, bebas dan tepat waktu dan akan mengurangi efektivitas pengembangan pengetahuan dan inovasi. Kemampuan peneliti asing di AS untuk bepergian ke luar negeri untuk menghadiri pertemuan ilmiah dan konferensi akan dibatasi, seperti juga kemampuan ilmuwan asing untuk menghadiri pertemuan ilmiah atau mengunjungi institusi ilmiah di AS.

Kita harus waspada untuk tidak membiarkan kefanatikan dan kebencian menyelinap kedalam masyarakat dan dirasionalisasi dengan kedok "melindungi rakyat." Jika kita tidak melakukan apapun untuk menghapuskan penargetan terhadap umat Islam, dapat dipastikan bahwa kelompok minoritas lainnya akan perlahan ditargetkan juga, apakah itu dengan menutup perbatasan dengan kelompok "berbahaya" lainnya atau menginjak-injak hak asasi mereka dengan cara yang berbeda-beda.

\section{KESIMPULAN}

Amerika Serikat selalu dikenal sebagai negara yang bebas dan penuh dengan kesempatan. Selama bertahuntahun, Amerika Serikat adalah tempat dimana orang-orang dari seluruh dunia bisa datang dan memulai kehidupan

\footnotetext{
9 "International Covenant on Civil and

Political Rights". United Nations"

${ }^{10}$ Ibid
} 
Vol.04, No.02, Bulan 2018

Doi: $10.24198 /$ cosmogov.v2i2.xxxxx

baru untuk diri mereka sendiri dan keluarga mereka. Kebanyakan orang dari beberapa generasi terakhir di Amerika akan mengatakan bahwa kakek dan nenek mereka adalah imigran dari negara lain. Tidak hanya negara-negara Muslim, tapi juga tempat-tempat seperti Italia, Meksiko, Kuba, Portugal, dll. Jika larangan bepergian ini diberlakukan saat mereka datang ke sini, Amerika pasti tidak menjadi negara seperti sekarang. Jika bertanya kepada siapa asal kakek dan nenek mereka, saya yakin sebagian besar akan mengatakan negara lain selain Amerika. Inilah salah satu alasan mengapa larangan perjalanan itu tidak masuk akal. Pada dasarnya kebijakan ini mengambil salah satu hal utama yang membuat Amerika menjadi tempat tinggal mereka, tempat orangorang datang karena mereka yakin akan disambut.

Kebijakan Trump ini memiliki sisi pro dan kontra yang tidak bisa dihindarkan. Mereka harus mementingkan keselamatan dan keamanan negara itu sendiri terdahulu baru dapat mengamankan dunia. Namun, dengan kebijakan yang sangat diskriminatif ini hanya akan memicu perpecahan dan menambah teror yang dapat dibuat mudah oleh para ekstrimis, walaupun mereka bukanlah sekelompok pengungsi atau imgran di Amerika Serikat.

Kebijakan itu tidak berdasar. Serangan 11 September digunakan sebagai alasan, sementara kebijakan ini membebaskan negara-negara asal para pembajak yang melakukan teror dan juga, mungkin tidak secara kebetulan, beberapa negara tempat keluarga Trump melakukan bisnis. Dokumen tersebut tidak secara eksplisit menyebutkan agama apapun, namun ini menetapkan standar inkonstitusional yang terang-terangan dengan mengecualikan umat Islam sambil memberi wewenang kepada pejabat pemerintah untuk mengakui orangorang dari agama lain.

Sebagai warga negara Indonesia yang notabenenya tinggal di negara yang berpenduduk dengan mayoritas agama Islam, kita tidak boleh hanya berpangku tangan dan menyaksikan ketidak adilan yang terjadi di dunia, walaupun kita tidak terkena imbasnya. Kita tidak hanya harus melawan semua kebijakan yang merugikan agama, rasa atau suku kita sendiri, namun semua kebijakan yang bertentangan dengan toleransi dan kebersamaan semua suku, agama dan ras harus kita hindari, jika perlu kita lawan. Karena, kebijakan kebijakan tersebut tidak hanya terjadi di Amerika Serikat, bisa saja kebijakan kebijakan seperti tersebut bisa saja terjadi atau diberlakukan di Indonesia. Oleh karena itu sudah seharusnya kita melawan apabila muncul bibit - bibit diskriminasi, intoleransi, ataupun kebijakan yang kesannya mengkotak kotakkan perbedaan. Karena seharusnya perbedaan itu merupakan sebuah berkah dari Tuhan karena semakin memperkaya kebudayaan Negara. 
Vol.04, No.02, Bulan 2018

Doi: 10.24198/cosmogov.v2i2.xxxxx

Banyak orang-orang diluar sana yang menderita akibat dari kebijakan ini yang sangat rasis dan diskriminatif. Yang dibutuhkan adalah tindakan untuk menghapuskan perpecahan dan menciptakan komunitas toleran terhadap berbagai agama dan etnis, ras dan identitas seksual. Masih banyak lagi yang menyatukan orang daripada memisahkan orang: komunitas, keluarga, dan hak untuk bebas dari diskriminasi. Saat kita berdiri bersama, kita mempererat kesatuan kita yang esensial.

\section{DAFTAR PUSTAKA}

Korostelina, K. (2017). Trump Effect.

Nowrasteh, A. (2016). Terrorism and

Immigration: A Risk Analysis.

Cato Institute.

Register, F. (2017). Public Inspection:

Presidential Document:

Defense and National Security:

Foreign Terrorists; Measures

to Prevent U.S. Entry (EO

13769).

Zick, A., Küpper, B., \& Andreas, H. (2011). An European Report. Intolerance, Prejudice and Discrimination, 39. 